\title{
AGRONOMIC CHARACTERIZATION AND GENETIC PARAMETER ESTIMATION IN YELLOW PASSION FRUIT
}

\author{
CARACTERIZAÇÃO AGRONÔMICA E ESTIMATIVA DE PARÂMETROS GENÉTICOS \\ EM MARACUJAZEIRO AZEDO
}

\author{
Hugo de Souza Motta MOREIRA ${ }^{1}$; Anne Pinheiro COSTA ${ }^{1}$; José Ricardo PEIXOTO' ${ }^{1}$; \\ Michelle Souza VILELA ${ }^{1}$; Márcio de Carvalho PIRES ${ }^{1}$; Nilton Tadeu Vilela JUNQUEIRA ${ }^{2}$ \\ 1. Faculdade de Agronomia e Medicina Veterinária, Universidade de Brasília, Campus Darcy Ribeiro, Brasília, DF, Brasil. \\ annecosta@gmail.com; 2. Empresa Brasileira de Pesquisa Agropecuária, Embrapa, Planaltina, DF, Brasil
}

\begin{abstract}
The selection of yellow passion fruit (Passiflora edulis Sims) genotypes with high yield and fruit quality is essential for the development of passion fruit crop in the country. Therefore, the objective of this study was to evaluate the agronomic performance and estimate the genetic parameters of 32 yellow passion fruit genotypes cultivated in the Federal District, Brazil. The experiment consisted of randomized block design with 32 treatments, eight plants per plot, and four replications. Fruits were classified based on their equatorial diameter. Yield, number of fruits per hectare, and fruit weight were evaluated. Genotypes MAR20\#23 and UnB-P7 presented the highest total yield, and MAR20\#23 also showed the greatest total number of fruits per hectare. BRS GA1 and MAR20\#23 had the best performance for industrial purposes dues to the fruits of smaller diameter classes. UnB-P7, AR-01, and MSC were more indicated for in natura consumption owing to the fruits of greater diameter classes. The high magnitude estimates for heritability and genetic variation coefficients indicate the possibility of greater genetic gains with direct selection for yield and number of fruits of 1C diameter class. Significant phenotypic correlations were observed, indicating the possibility of indirect selection for number of fruits, fruit weight, and yield.
\end{abstract}

KEYWORDS: Agronomic performance. Plant breeding. Passion fruit cultivation.

\section{INTRODUCTION}

Brazil stands out as the world's largest producer and consumer of passion fruit. In 2016, fruit production reached 703,489 tons in an area of 49,889 hectares (IBGE, 2016). Yellow passion fruit (Passiflora edulis Sims), also known as sour passion fruit, represents approximately $95 \%$ of the national production (COSTA et al., 2008). The Brazilian passion fruit mean yield $\left(14.10 \mathrm{t} \mathrm{ha}^{-1}\right)$ (IBGE, 2016) is considered as low when compared with the productive potential of the species, which can reach more than 40 $\mathrm{t} \mathrm{ha}^{-1}$ (FREITAS et al., 2011; NEVES et al., 2013). The cultivation of inadequate varieties (JUNQUEIRA et al., 1999), the low production technology usage (MELO et al., 2001), and the lack of homogeneous and productive materials (MELETTI et al., 2000) are limiting factors to the increase of fruit quality and orchards yield.

The development of genotypes with high yield, uniformity, and fruit quality is important for breeding programs (FALEIRO et al., 2006) since they increase the species production potential (NEVES et al., 2013). In addition, these materials may increase the producers' income and simplify some stages of the productive process, such as post-harvest fruit classification (MELETTI et al., 2000).

Fruit quality is measured both by its internal and external characteristics. The former is related to flavor (acidity and sugars content) and juice content (yield). The latter is associated with appearance and fruit standardization parameters, which influence the consumer's choice. Fruits with better external appearance are usually intended for the fresh fruit market, while the others are destined for the industry (BALBINO, 2005). Therefore, the objective of this study was to evaluate the agronomic performance of 32 yellow passion fruit genotypes cultivated in the Federal District, Brazil, and to estimate some essential genetic parameters for the definition of breeding strategies.

\section{MATERIAL AND METHODS}

The experiment was conducted at Água Limpa Farm, belonging to University of Brasilia (UnB) $\left(16^{\circ} \mathrm{S}\right.$ and $48^{\circ} \mathrm{W}, 1,100 \mathrm{~m}$ asl), located in Brasilia, DF, Brazil. It consisted of a randomized 
block design, with 32 treatments, eight plants per plot, and four replications. The genotypes evaluated in this study were obtained from Embrapa and UnB and were selected based on yield, fruit quality, and resistance to diseases. The plants were arranged in the field, spaced $2.75 \mathrm{~m}$ between rows, and $3 \mathrm{~m}$ between plants, totaling 1,024 useful plants, with external border. The experiment was carried out in Clayey Red-Yellow Latosol; soils were deep, well drained, and low fertile. Soil analysis presented the following results: $\mathrm{Al}(0.05$ meq); $\mathrm{Ca}+\mathrm{Mg}$ (1.9 meq); P (4.5 ppm); K (46 ppm); $\mathrm{pH} 5.4$; and $4 \% \mathrm{Al}$ saturation. Liming was applied, and $1 \mathrm{~kg}$ of simple superphosphate per pit was incorporated at the pre-planting stage. Monthly topdressings were performed in a circle, at a distance of 40 to $50 \mathrm{~cm}$ from the stem, while simple superphosphate was incorporated into the soil. The crop was managed using a trellis fence system comprised of $6 \mathrm{~m}$-distant wooden stakes and two pieces of smooth wire, at 1.60 and $2.20 \mathrm{~m}$ from the ground. Formation pruning was performed. The crop was daily watered by a drip irrigation system, with the application of approximately $5 \mathrm{~L} \mathrm{~m}^{-2}$ of water. Drippers were spaced at $30 \mathrm{~cm}$ apart. Weeds were controlled by periodic hoeing between rows and postemergent herbicides in the rows. No chemical control of diseases or artificial pollination was performed to increase fruiting during the experiment evaluation period.

The agronomic performance was evaluated at one year after planting, from November 2009 to April 2010, totaling 20 harvests. Fruits were weekly harvested from the ground, weighed, and classified according to their equatorial diameter (D), as follows: $1 \mathrm{C}(\mathrm{D} \leq 55 \mathrm{~mm}) ; 1 \mathrm{~B}(55<\mathrm{D} \leq 65 \mathrm{~mm}) ; 1 \mathrm{~A}(65<\mathrm{D} \leq$ $75 \mathrm{~mm}) ; 2 \mathrm{~A}(75<\mathrm{D} \leq 90 \mathrm{~mm}) ; 3 \mathrm{~A}(\mathrm{D}>90 \mathrm{~mm})$ (ABREU et al., 2009). Estimated yield $\left(\mathrm{kg} \mathrm{ha}^{-1}\right)$ and number of fruits per hectare (considering 9,697 plants per hectare), and fruit weight (g) were evaluated for all diameter classes together (total), as well as for each diameter class.

Data were subject to analysis of variance, and means were compared by the Tukey's test, at 5\% probability. Mean genotypic $\left(\sigma_{\mathrm{g}}^{2}\right)$, phenotypic $\left(\sigma_{\mathrm{p}}^{2}\right)$, and environmental $\left(\sigma_{\mathrm{e}}^{2}\right)$ estimates; mean broad sense heritability $\left(\mathrm{h}^{2}\right)$; and coefficients of experimental $\left(\mathrm{CV}_{\mathrm{e}}\right)$ and genetic $\left(\mathrm{CV}_{\mathrm{g}}\right)$ variation were obtained for each of the variables analyzed. A phenotypic correlation was calculated between the variables, using the following expression:

$$
r_{f}=\frac{C \hat{o} v_{f}(X, Y)}{\sqrt{\sigma_{f}^{2}(X) \cdot \sigma_{f}^{2}(Y)}}
$$

where $C \hat{o} v_{f}(X, Y)$ is

the estimator of phenotypic covariance between two traits $\mathrm{X}$ and $\mathrm{Y} ; \sigma_{f}^{2}(X)$ is the estimator of the phenotypic variance of trait $\mathrm{X}$; and $\sigma_{f}^{2}(Y)$ is the estimator of the phenotypic variance of trait $\mathrm{Y}$.

The intensity of the correlation was classified based on the magnitude of the values, as suggested by Carvalho et al. (2004): $\mathrm{r}=0$ (null); $0<|\mathrm{r}| \leq 0.30$ (weak); $0.30<|\mathrm{r}| \leq 0.60$ (intermediate); $0.60<|\mathrm{r}| \leq$ 0.90 (strong); $0.90<|r| \leq 1$ (very strong); and $|r|=1$ (perfect). All statistical analyses were performed using the Genes software (CRUZ, 2013).

\section{RESULTS AND DISCUSSION}

Significant differences were observed between genotypes for all traits, except for fruit weight of diameter classes 2A and 3A. Studies carried out with yellow passion fruit progenies have demonstrated high genetic variability for some traits, such as number of fruits per plant, and fruit weight and length (FREITAS et al., 2012; KRAUSE et al., 2012). This variability evidences the breeding potential of genotypes selection (OLIVEIRA et al., 2008).

The total yield varied from 4,055.19 (EC-3-0) to $15,474.39 \mathrm{~kg} \mathrm{ha}^{-1}$ (MAR20\#23), with a mean of $9,543.88 \mathrm{~kg} \mathrm{ha}^{-1}$ for all genotypes (Table 1). For some of the genotypes studied, the total yield was higher than the national mean (IBGE, 2015). Studies on the agronomic traits of different yellow passion fruit genotypes cultivated in the Federal District have demonstrated distinct behavior for EC-3-0. According to these data, genotype EC-3-0 presented superior performance, with a total yield of 15,460 (ABREU et al., 2009) and 26,480 kg ha ${ }^{-1}$ (JUNQUEIRA et al., 2003). Coimbra et al. (2012), Maia et al. (2009), and Junqueira et al. (2003) observed a superior performance for EC-RAM in relation to the other genotypes, with an estimated total yield of 43,287; 13,968; and 32,880 $\mathrm{kg} \mathrm{ha}^{-1}$, respectively. However, in the present study, EC-RAM exhibited a total yield of only $6,350.40 \mathrm{~kg} \mathrm{ha}^{-1}$.

The total number of fruits per hectare ranged from 31,063 (UnB-P5) to 119,715 (MAR20\#23). In general, the most productive genotypes also presented the greatest number of fruits. Although they did not 
significantly differ, a considerable numerical variation of 52,000 fruits between AR-01 and EC-RAM was recorded. These fruits, in practical terms, could be commercialized (Table 1). MAR20\#23 can produce
342,847 fruits per hectare in the edaphoclimatic conditions of the Federal District (COIMBRA et al., 2012), confirming the superior performance of the genotype in this region.

Table 1. Total yield (TY; $\mathrm{Kg} \mathrm{ha}^{-1}$ ), number of fruits per hectare (TNF), and fruit weight (TFW; g) in 32 yellow passion fruit (Passiflora edulis Sims) genotypes cultivated in Brasilia, DF, Brazil.

\begin{tabular}{lccc}
\hline \multicolumn{1}{c}{ Genotype } & TY & TNF & TFW \\
\hline UnB-P6 & $12,213.28 \mathrm{abc}$ & $86,729.25 \mathrm{abcd}$ & $137.06 \mathrm{a}$ \\
MAR20\#40 & $9,742.20 \mathrm{abc}$ & $86,582.06 \mathrm{abcd}$ & $114.56 \mathrm{ab}$ \\
UnB-P1 & $8,353.54 \mathrm{abc}$ & $68,512.06 \mathrm{abcd}$ & $125.56 \mathrm{ab}$ \\
MAR20\#29 & $4,219.94 \mathrm{bc}$ & $35,720.00 \mathrm{~cd}$ & $120.00 \mathrm{ab}$ \\
MAR22\#2005 & $9,886.31 \mathrm{abc}$ & $79,100.56 \mathrm{abcd}$ & $125.56 \mathrm{ab}$ \\
Roxo Australiano & $5,369.65 \mathrm{abc}$ & $62,874.56 \mathrm{abcd}$ & $84.56 \mathrm{~b}$ \\
MAR20\#15 & $12,659.36 \mathrm{abc}$ & $97,187.06 \mathrm{abcd}$ & $131.25 \mathrm{ab}$ \\
MSC & $5,149.49 \mathrm{abc}$ & $33,123.00 \mathrm{~cd}$ & $155.25 \mathrm{a}$ \\
RC-3 & $5,129.09 \mathrm{abc}$ & $39,899.06 \mathrm{bcd}$ & $125.56 \mathrm{ab}$ \\
Rubi Gigante & $10,499.22 \mathrm{abc}$ & $85,994.56 \mathrm{abcd}$ & $120.00 \mathrm{ab}$ \\
AR-01 & $13,996.95 \mathrm{abc}$ & $102,879.56 \mathrm{abcd}$ & $137.06 \mathrm{a}$ \\
AR-02 & $8,791.22 \mathrm{abc}$ & $69,827.06 \mathrm{abcd}$ & $125.56 \mathrm{ab}$ \\
MAR20\#49 & $8,258.44 \mathrm{abc}$ & $68,250.56 \mathrm{abcd}$ & $120.00 \mathrm{ab}$ \\
BRS Sol Cerrado & $7,663.21 \mathrm{abc}$ & $61,627.06 \mathrm{abcd}$ & $125.56 \mathrm{ab}$ \\
MAR20\#6 & $13,010.45 \mathrm{abc}$ & $104,005.25 \mathrm{abc}$ & $120.00 \mathrm{ab}$ \\
UnB-P5 & $4,601.02 \mathrm{abc}$ & $31,063.06 \mathrm{~d}$ & $137.06 \mathrm{a}$ \\
MAR20\#23 & $15,474.39 \mathrm{a}$ & $119,715.00 \mathrm{a}$ & $125.56 \mathrm{ab}$ \\
UnB-P4 & $10,916.42 \mathrm{abc}$ & $83,087.06 \mathrm{abcd}$ & $125.56 \mathrm{ab}$ \\
UnB-P2 & $12,164.40 \mathrm{abc}$ & $106,601.25 \mathrm{abc}$ & $109.25 \mathrm{ab}$ \\
UnB-P7 & $14,663.15 \mathrm{ab}$ & $102,879.56 \mathrm{abcd}$ & $149.06 \mathrm{a}$ \\
MAR20\#03 & $13,149.69 \mathrm{abc}$ & $101,123.00 \mathrm{abcd}$ & $125.56 \mathrm{ab}$ \\
EC-3-0 & $4,055.19 \mathrm{c}$ & $37,055.25 \mathrm{~cd}$ & $109.25 \mathrm{ab}$ \\
MAR20\#10 & $9,282.68 \mathrm{abc}$ & $90,299.25 \mathrm{abcd}$ & $104.06 \mathrm{ab}$ \\
MAR20\#34 & $11,085.57 \mathrm{abc}$ & $99,855.00 \mathrm{abcd}$ & $109.25 \mathrm{ab}$ \\
MAR20\#21 & $13,647.48 \mathrm{abc}$ & $118,507.06 \mathrm{ab}$ & $109.25 \mathrm{ab}$ \\
FB200 & $10,578.75 \mathrm{abc}$ & $81,509.25 \mathrm{abcd}$ & $131.25 \mathrm{ab}$ \\
FP-01 & $8,529.32 \mathrm{abc}$ & $72,494.56 \mathrm{abcd}$ & $114.56 \mathrm{ab}$ \\
BRS GA1 & $11,035.68 \mathrm{abc}$ & $105,949.25 \mathrm{abc}$ & $104.06 \mathrm{ab}$ \\
EC-RAM & $6,350.40 \mathrm{abc}$ & $50,962.06 \mathrm{abcd}$ & $125.56 \mathrm{ab}$ \\
GA2 & $10,873.51 \mathrm{abc}$ & $92,415.00 \mathrm{abcd}$ & $120.00 \mathrm{ab}$ \\
Redondão & $8,278.57 \mathrm{abc}$ & $70,356.56 \mathrm{abcd}$ & $109.25 \mathrm{ab}$ \\
MAR20\#39 & $5,775.61 \mathrm{abc}$ & $49,616.56 \mathrm{abcd}$ &
\end{tabular}

Different lowercase letters in the columns indicate significant differences (Tukey's test, $\mathrm{P} \leq 0.05$ ).

Fruits of diameter classes $1 \mathrm{C}$ and $1 \mathrm{~B}$ are of great interest to the industry for being small and usually rejected by the fresh fruit market. Fruits of greater diameter classes $(1 \mathrm{~A}, 2 \mathrm{~A}$, and $3 \mathrm{~A})$ are intended for the in natura market (COIMBRA et al., 2012). The highest yield and the greatest number of fruits of 1C diameter class were observed in BRS GA1, with $3,343.41 \mathrm{~kg} \mathrm{ha}^{-1}$ and 53,939 fruits, respectively. MSC presented the lowest yield and number of fruits of $1 \mathrm{C}$ diameter class, with $238.14 \mathrm{~kg}$ $\mathrm{ha}^{-1}$ and 4,455 fruits. For 1B diameter class, MAR20\#23 presented the highest yield $(9,019.51 \mathrm{~kg}$ $\left.\mathrm{ha}^{-1}\right)$ and the greatest number of fruits $(62,875)$. MSC showed the lowest yield $\left(2,295.98 \mathrm{~kg} \mathrm{ha}^{-1}\right)$ and UnBP5 showed the lowest number of fruits $(16,192)$. For fruits classified as $1 \mathrm{~A}, \mathrm{UnB}-\mathrm{P} 7$ presented the highest 
yield $\left(4.156 .60 \mathrm{~kg} \mathrm{ha}^{-1}\right)$ and number of fruits $(19,251)$. In contrast, EC-3-0 showed the lowest yield $(643,60$ $\left.\mathrm{kg} \mathrm{ha}^{-1}\right)$, and MAR20\#29 exhibited the lowest number of fruits $(3,480)$ (Table 2$)$.

Low yields were observed for larger fruits ( $2 \mathrm{~A}$ and $3 \mathrm{~A}$ ) when compared with the other diameter classes. For $2 \mathrm{~A}$ diameter class, AR-01 presented the greatest fruit yield $\left(639.99 \mathrm{~kg} \mathrm{ha}^{-1}\right)$ and the greatest number of fruits (2449), differing only from genotype MAR20\#29, which registered $2.86 \mathrm{~kg} \mathrm{ha}^{-1}$ and 13 fruits (Table 2). This result corroborates other studies that reported the superior performance of AR-01 in relation to fruit yield and number of fruits in the diameter classes 1A and 2A (ABREU et al., 2009; MAIA et al., 2009; COIMBRA et al., 2012). For the fruits of 3A diameter class, MSC presented the best performance, with $115.94 \mathrm{~kg} \mathrm{ha}^{-1}$ and 409 fruits (Table 2).

Greater fruit weight is fundamental to the fresh fruit market. Larger fruits have better commercial classification and, consequently, better prices. Neves et al. (2013) stated that fruits with fruit weight greater than $180 \mathrm{~g}$ present good commercial value for the fresh fruit market. The total weight per fruit ranged between $84.56 \mathrm{~g}$ (Roxo Australiano) and $155.25 \mathrm{~g}$ (MSC), with a mean weight of $121.58 \mathrm{~g}$ for all genotypes evaluated (Table 1). Coimbra et al. (2012) reported similar results for genotypes AR-01, AR-02, MAR20\#03, FP-01, RC-3, and EC-RAM, and did not detect differences between genotypes. However, the fruit weight range obtained in this study, as well as that reported by Coimbra et al. (2012), was lower than the variations recorded by Campos et al. (2007) (191 and $228 \mathrm{~g}$ fruit $\left.^{-1}\right)$ and by Vale et al. (2013) (207 and $\left.286 \mathrm{~g} \mathrm{fruit}^{-1}\right)$. Considering the diameter classes $1 \mathrm{C}$ and $1 \mathrm{~B}$, genotypes UnB-P7 $(71.25 \mathrm{~g})$ and MAR20\#15 (155.25 g) presented the highest fruit weight, respectively, while genotypes EC-RAM (38.06 g) and Roxo Australiano (99.00 g) showed the lowest values, respectively. UnB-P5 obtained the greatest fruit weight in the $1 \mathrm{~A}$ diameter class $(231.56 \mathrm{~g})$, differing only from EC-3-0 (174.56 g). No significant differences were recorded between fruit weight in the diameter classes $2 \mathrm{~A}$ and $3 \mathrm{~A}$ for the different genotypes (Table 2).

The contrasts observed among the different studies may be due to the genetic nature of the analyzed materials since they are originated from open pollination. Additionally, different water and nutritional management, distinct harvest times, different substrates and packages used for seedling formation, plant physiological conditions, and environmental factors favorable to the occurrence of phytopathogens may have contributed to these variations. The pollination type should also be considered since it influences fruiting. Artificial pollination, which was not performed in the present study, would have substantially increased yield, fruit weight, fruit diameter and length, and percentage of pulp; and reduced peel thickness (KRAUSE et al., 2012). Such traits would favor both the fresh fruit market and the industry. Fruits with greater pulp weight and size are preferred by the in natura market. Conversely, high pulp yield and reduced peel thickness are desirable traits for industrial purposes (FERREIRA et al., 2010).

The three variables evaluated presented heritability estimates of high magnitude (Table 3). The $\mathrm{CV}_{\mathrm{g}}$ for the variables total yield (14.70), total number of fruits (15.06), and total fruit weight (4.09) were low when compared with the results obtained by Freitas et al. (2011) (Table 3). These low values may indicate the existence of low genetic variability among the evaluated genotypes.

Heritability values ranged from 8.17 (fruit weight of $2 \mathrm{~A}$ diameter class) to $81.70 \%$ (number of fruits of 1C diameter class) (Table 4). Considering the magnitudes of heritability estimates and the $\mathrm{CV}_{\mathrm{g}}$, higher gains with direct selection are expected for yield and number of fruits of $1 \mathrm{C}$ diameter class since the environment has little influence on the expression of these traits. Oliveira et al. (2008) reported the highest estimates of coefficients of heritability (greater than 50\%) for fruit length, number of fruits per plant, and fruit weight. Similarly, Freitas et al. (2011) reported high heritability values for the number of fruits per plot $(98.02 \%)$ and fruit length $(82.69 \%)$.

Despite the low $\mathrm{CV}_{\mathrm{g}}$ observed for the different diameter classes, the $\mathrm{CV}_{\mathrm{g}} / \mathrm{CV}_{\mathrm{e}}$ ratio was greater than 1 for number of fruits of $1 \mathrm{C}$ diameter class (1.06) and total fruit yield for the same diameter class (1.02) (Table 4). These values indicate a favorable selection condition since the genetic variance surpasses the environmental variance. These variables also presented the highest heritability estimates, contributing to the values of $\mathrm{CV}_{\mathrm{g}} / \mathrm{CV}_{\mathrm{e}}$ ratio. For the other variables, $\mathrm{CV}_{\mathrm{g}} / \mathrm{CV}_{\mathrm{e}}$ ratio was lower than 1 , indicating that the use of simple breeding methods, such as mass selection, will not provide significant gains during the selection process. Breeding methods based on family performance are more appropriate 
than those based on individual performance (FREITAS et al., 2015).

Seventy significant phenotypic correlations were observed, with valuesvarying between 0.34 and 0.99 . In $60 \%$ of the significant correlations, estimates values were equal to or greater than 0.6 , indicating a strong correlation and the possibility of indirect selection for these traits. The presence of significance for low correlation values has been detected by other authors (VASCONCELOS et al., 1998; KUREK et al., 2002), and may be associated with the high degrees of freedom included in the t-test (VASCONCELOS et al., 1998) (Table 5). In this study, the increase in the total number of fruits increased the total yield $\left(r_{f}=0.96\right)$, as also reported in other studies (OLIVEIRA et al., 2011; NEVES et al., 2013). Similarly, Pimentel et al. (2008) recorded a strong phenotypic correlation between number of fruits and yield per plant. Strong phenotypic correlations were observed between number of fruits and fruit yield for each diameter class: 1C $\left(\mathrm{r}_{\mathrm{f}}=0.98\right)$, $1 \mathrm{~B}\left(\mathrm{r}_{\mathrm{f}}=0.97\right), 1 \mathrm{~A}\left(\mathrm{r}_{\mathrm{f}}=0.99\right), 2 \mathrm{~A}\left(\mathrm{r}_{\mathrm{f}}=0.99\right), 3 \mathrm{~A}\left(\mathrm{r}_{\mathrm{f}}=\right.$ 0.98). For fruits of $3 \mathrm{~A}$ diameter class, a strong correlation was reported between number of fruits and fruit weight $\left(r_{f}=0.92\right)$, and between fruit yield and fruit weight $\left(r_{f}=0.94\right)$ (Table 5). 
Agronomic characterization.

MOREIRA, H. S. M. et al.,

Table 2. Yield ( $\mathrm{Y} ; \mathrm{Kg} \mathrm{ha}^{-1}$ ), number of fruits per hectare (NF), and fruit weight (FW; g) of diameter classes 1C, 1B, 1A, 2A, and 3A in 32 yellow passion fruit (Passiflora edulis Sims) genotypes cultivated in Brasilia, DF, Brazil.

\begin{tabular}{|c|c|c|c|c|c|c|}
\hline Genotype & Y1C & NF1C & FW1C & Y1B & NF1B & FW1B \\
\hline UnB-P6 & $1,621.8$ abcde & $25,200.56$ abcdef & $67.06 \mathrm{ab}$ & $7,082.25 \mathrm{ab}$ & $45,795.00 \mathrm{ab}$ & $149.06 \mathrm{ab}$ \\
\hline MAR20\#40 & $2,555.2 \mathrm{abc}$ & $39,401.25$ abcd & $63.00 \mathrm{ab}$ & $5,683.45 a b c$ & $39,999.00 \mathrm{ab}$ & $143.00 \mathrm{ab}$ \\
\hline UnB-P1 & 857.94 cde & $16,575.56 \mathrm{cdef}$ & $51.56 \mathrm{ab}$ & $5,161.98 \mathrm{abc}$ & $41,208.00 \mathrm{ab}$ & $125.56 \mathrm{ab}$ \\
\hline MAR20\#29 & $616.22 \mathrm{cde}$ & $11,341.25$ cdef & $51.56 \mathrm{ab}$ & $2,843.44 \mathrm{abc}$ & $20,519.56 a b$ & $131.25 \mathrm{ab}$ \\
\hline MAR22\#2005 & 1,769.56 abcd & 28,644.56 abcde & $63.00 \mathrm{ab}$ & $5,770.8 \mathrm{abc}$ & $39,600.00 \mathrm{ab}$ & $143.00 \mathrm{ab}$ \\
\hline Roxo Australiano & 771.32 cde & $16,769.25$ bcdef & $44.56 \mathrm{ab}$ & $3,378.24$ abc & $37,732.06 \mathrm{ab}$ & $99.00 \mathrm{~b}$ \\
\hline MAR20\#15 & 2,000.81 abcd & 31,772.06 abcde & $63.00 \mathrm{ab}$ & $7,823.21 \mathrm{abc}$ & $51,983.00 \mathrm{ab}$ & $155.25 \mathrm{a}$ \\
\hline MSC & $238.14 \mathrm{e}$ & $4,454.56 \mathrm{f}$ & $51.56 \mathrm{ab}$ & $2,295.98 \mathrm{c}$ & $16,383.00 \mathrm{~b}$ & $143.00 \mathrm{ab}$ \\
\hline $\mathrm{RC}-3$ & $503.04 \mathrm{de}$ & $9,949.06 \mathrm{ef}$ & $44.56 \mathrm{ab}$ & $2,960.11 \mathrm{abc}$ & $21,903.00 \mathrm{ab}$ & $125.56 \mathrm{ab}$ \\
\hline Rubi Gigante & 1,745.04 abcd & 29,583.00 abcde & $55.25 \mathrm{ab}$ & $6,326.48$ abc & $45,368.00 \mathrm{ab}$ & $143.00 \mathrm{ab}$ \\
\hline AR-01 & 1,661.52 abcde & $27,059.25$ abcde & $63.00 \mathrm{ab}$ & $7,886.28 \mathrm{abc}$ & $55,813.06 \mathrm{ab}$ & $137.06 \mathrm{ab}$ \\
\hline AR-02 & 839.06 cde & $14,640.00 \mathrm{cdef}$ & $55.25 \mathrm{ab}$ & $5,164.26 \mathrm{abc}$ & $40,601.25 \mathrm{ab}$ & $120.00 \mathrm{ab}$ \\
\hline MAR20\#49 & $939.45 \mathrm{cde}$ & 20,519.56 abcdef & $48.00 \mathrm{ab}$ & $4,204.55 \mathrm{abc}$ & $33,214.06 \mathrm{ab}$ & $125.56 \mathrm{ab}$ \\
\hline BRS Sol Cerrado & $802.37 \mathrm{cde}$ & $14,160.00 \mathrm{cdef}$ & $55.25 \mathrm{ab}$ & $4,229.19 \mathrm{abc}$ & $34,595.00 \mathrm{ab}$ & $120.00 \mathrm{ab}$ \\
\hline MAR20\#6 & $1,950.21 \mathrm{abcd}$ & 31,328.00 abcde & $63.00 \mathrm{ab}$ & $8,305.92 \mathrm{abc}$ & $59,657.06 \mathrm{a}$ & $137.06 \mathrm{ab}$ \\
\hline UnB-P5 & $549.08 \mathrm{de}$ & $8,234.56$ ef & $63.00 \mathrm{ab}$ & $2,540.04 \mathrm{bc}$ & $16,191.56$ b & $149.06 \mathrm{ab}$ \\
\hline MAR20\#23 & $2,581.64 \mathrm{abc}$ & $38,024.00 \mathrm{abcd}$ & $67.06 \mathrm{ab}$ & $9,019.51 \mathrm{a}$ & $62,874.56 \mathrm{a}$ & $143.00 \mathrm{ab}$ \\
\hline UnB-P4 & 877.5 cde & $15,251.25 \mathrm{cdef}$ & $55.25 \mathrm{ab}$ & $6,484.66 \mathrm{abc}$ & $49,394.06 \mathrm{ab}$ & $131.25 \mathrm{ab}$ \\
\hline UnB-P2 & $2,559.20 \mathrm{abc}$ & 39,302.06 abcd & $67.06 \mathrm{ab}$ & $6,524.19 a b c$ & $52,325.56 \mathrm{ab}$ & $120.00 \mathrm{ab}$ \\
\hline UnB-P7 & 2,019.95 abcd & 28,644.56 abcde & $71.25 \mathrm{a}$ & $7,752.05 \mathrm{abc}$ & $51,983.00 \mathrm{ab}$ & $149.06 \mathrm{ab}$ \\
\hline MAR20\#03 & $1,737.78 \mathrm{abcd}$ & 30,536.56 abcde & $55.25 \mathrm{ab}$ & 7,914.37 abc & $54,989.25 \mathrm{ab}$ & $149.06 \mathrm{ab}$ \\
\hline EC-3-0 & $651.25 \mathrm{cde}$ & $11,288.06 \mathrm{def}$ & $55.25 \mathrm{ab}$ & $2,621.97 \mathrm{abc}$ & $20,735.00 \mathrm{ab}$ & $120.00 \mathrm{ab}$ \\
\hline MAR20\#10 & 2,057.79 abcd & $38,906.56 \mathrm{abcd}$ & $55.25 \mathrm{ab}$ & $5,296.9 \mathrm{abc}$ & $41,411.25 \mathrm{ab}$ & $131.25 \mathrm{ab}$ \\
\hline MAR20\#34 & 2,240.26 abcd & $39,899.06$ abc & $55.25 \mathrm{ab}$ & $6,498.67 \mathrm{abc}$ & $48,619.25 \mathrm{ab}$ & $131.25 \mathrm{ab}$ \\
\hline MAR20\#21 & $3,259.83 \mathrm{ab}$ & 49,394.06 ab & $63.00 \mathrm{ab}$ & $8,792.71 \mathrm{ab}$ & $61,131.56 \mathrm{a}$ & $137.06 \mathrm{ab}$ \\
\hline FB200 & 1,977.54 abcd & 28,055.25 abcde & $67.06 \mathrm{ab}$ & $6,959.04 \mathrm{abc}$ & $46,009.25 \mathrm{ab}$ & $143.00 \mathrm{ab}$ \\
\hline FP-01 & $1,190.28$ abcde & $21,903.00$ abcdef & $55.25 \mathrm{ab}$ & $5,542.49 \mathrm{abc}$ & $41,513.06 \mathrm{ab}$ & $131.25 \mathrm{ab}$ \\
\hline BRS GA1 & $3,343.41 \mathrm{a}$ & $53,939.06 \mathrm{a}$ & $63.00 \mathrm{ab}$ & $5,881.84 \mathrm{abc}$ & $42,641.25 \mathrm{ab}$ & $137.06 \mathrm{ab}$ \\
\hline EC-RAM & $680.21 \mathrm{cde}$ & $15,624.00 \mathrm{cdef}$ & $38.06 \mathrm{~b}$ & $3,621.41 \mathrm{abc}$ & $26,081.25 \mathrm{ab}$ & $137.06 \mathrm{ab}$ \\
\hline GA2 & $1,460.47$ abcde & $26,731.25$ abcde & $55.25 \mathrm{ab}$ & $7,014.55 \mathrm{abc}$ & $53,475.56 \mathrm{ab}$ & $131.25 \mathrm{ab}$ \\
\hline Redondão & $1,377.10$ abcde & $24,179.25$ abcdef & $59.06 \mathrm{ab}$ & $5,196.12 \mathrm{abc}$ & $38,219.25 \mathrm{ab}$ & $137.06 \mathrm{ab}$ \\
\hline MAR20\#39 & 973.18 bcde & $16,834.06$ bcdef & $55.25 \mathrm{ab}$ & $3,452.16 \mathrm{abc}$ & $25,599.00 \mathrm{ab}$ & $131.25 \mathrm{ab}$ \\
\hline
\end{tabular}

Different lowercase letters in the columns indicate significant differences (Tukey's test, $\mathrm{P} \leq 0.05$ ). 
Table 2. Continuation.

\begin{tabular}{|c|c|c|c|c|c|c|c|c|c|}
\hline Genotype & Y1A & NF1A & FW1A & Y2A & NF2A & FW2A & Y3A & NF3A & FW3A \\
\hline UnB-P6 & $3,076.52 \mathrm{ab}$ & $13,629.56 \mathrm{ab}$ & $224.00 \mathrm{ab}$ & $316.69 \mathrm{ab}$ & $1,313.06 \mathrm{ab}$ & $231.56 \mathrm{a}$ & $9.31 \mathrm{~b}$ & $41.25 \mathrm{~b}$ & $67.06 \mathrm{a}$ \\
\hline MAR20\#40 & $1,364.22 \mathrm{ab}$ & $6,723.00 \mathrm{ab}$ & $195.00 \mathrm{ab}$ & $7.40 \mathrm{ab}$ & $41.25 \mathrm{ab}$ & $55.25 \mathrm{a}$ & $0.00 \mathrm{~b}$ & $0.00 \mathrm{~b}$ & $0.00 \mathrm{a}$ \\
\hline UnB-P1 & $1,778.89 \mathrm{ab}$ & $8,601.56 \mathrm{ab}$ & $202.06 \mathrm{ab}$ & $449.57 \mathrm{ab}$ & $1.405 .25 \mathrm{ab}$ & $323.00 \mathrm{a}$ & $0.00 \mathrm{~b}$ & $0.00 \mathrm{~b}$ & $0.00 \mathrm{a}$ \\
\hline MAR20\#29 & $713.6 \mathrm{~b}$ & $3,480.00 \mathrm{~b}$ & $188.06 \mathrm{ab}$ & $2.86 \mathrm{~b}$ & $13.06 \mathrm{~b}$ & $24.00 \mathrm{a}$ & $0.00 \mathrm{~b}$ & $0.00 \mathrm{~b}$ & $0.00 \mathrm{a}$ \\
\hline MAR22\#2005 & $2,067.84 \mathrm{ab}$ & $9,554.06 \mathrm{ab}$ & $209.25 \mathrm{ab}$ & $233.05 \mathrm{ab}$ & $929.25 \mathrm{ab}$ & $239.25 \mathrm{a}$ & $0.00 \mathrm{~b}$ & $0.00 \mathrm{~b}$ & $0.00 \mathrm{a}$ \\
\hline Roxo Australiano & $1,119.36 \mathrm{ab}$ & $5,928.00 \mathrm{ab}$ & $174.56 \mathrm{ab}$ & $34.5 \mathrm{ab}$ & $161.56 \mathrm{ab}$ & $120.00 \mathrm{a}$ & $5.22 \mathrm{~b}$ & $35.00 \mathrm{~b}$ & $17.06 \mathrm{a}$ \\
\hline MAR20\#15 & $2,502.72 \mathrm{ab}$ & $11,555.25 \mathrm{ab}$ & $216.56 \mathrm{ab}$ & $154.84 \mathrm{ab}$ & $575.00 \mathrm{ab}$ & $143.00 \mathrm{a}$ & $0.00 \mathrm{~b}$ & $0.00 \mathrm{~b}$ & $0.00 \mathrm{a}$ \\
\hline MSC & $1,772.89 \mathrm{ab}$ & $9,024.00 \mathrm{ab}$ & $202.06 \mathrm{ab}$ & $608.40 \mathrm{ab}$ & $2.375 .56 \mathrm{ab}$ & $255.00 \mathrm{a}$ & $115.94 \mathrm{a}$ & $409.06 \mathrm{a}$ & $168.00 \mathrm{a}$ \\
\hline $\mathrm{RC}-3$ & $1,467.73 \mathrm{ab}$ & 7,097.06 ab & $209.25 \mathrm{ab}$ & $162.61 \mathrm{ab}$ & $769.06 \mathrm{ab}$ & $209.25 \mathrm{a}$ & $0.00 \mathrm{~b}$ & $0.00 \mathrm{~b}$ & $0.00 \mathrm{a}$ \\
\hline Rubi Gigante & $2,183.74 \mathrm{ab}$ & $9,899.25 \mathrm{ab}$ & $216.56 \mathrm{ab}$ & $174.72 \mathrm{ab}$ & $675.00 \mathrm{ab}$ & $149.06 \mathrm{a}$ & $0.00 \mathrm{~b}$ & $0.00 \mathrm{~b}$ & $0.00 \mathrm{a}$ \\
\hline AR-01 & $3,706.59 \mathrm{a}$ & $17,094.56 \mathrm{a}$ & $209.25 \mathrm{ab}$ & $639.99 \mathrm{a}$ & $2,449.25 \mathrm{a}$ & $263.06 \mathrm{a}$ & $13.05 \mathrm{ab}$ & $41.25 \mathrm{~b}$ & $94.06 \mathrm{a}$ \\
\hline AR-02 & $2,383.16 \mathrm{ab}$ & $12,044.06 \mathrm{ab}$ & $195.00 \mathrm{ab}$ & $276.41 \mathrm{ab}$ & $1,104.56 \mathrm{ab}$ & $255.00 \mathrm{a}$ & $0.00 \mathrm{~b}$ & $0.00 \mathrm{~b}$ & $0.00 \mathrm{a}$ \\
\hline MAR20\#49 & $2,374.68 \mathrm{ab}$ & $11,235.00 \mathrm{ab}$ & $216.56 \mathrm{ab}$ & $567.38 \mathrm{ab}$ & $2,184.56 \mathrm{ab}$ & $155.25 \mathrm{a}$ & $0.00 \mathrm{~b}$ & $0.00 \mathrm{~b}$ & $0.00 \mathrm{a}$ \\
\hline BRS Sol Cerrado & $2,256.75 \mathrm{ab}$ & $11,129.25 \mathrm{ab}$ & $202.06 \mathrm{ab}$ & $212.06 \mathrm{ab}$ & $840.00 \mathrm{ab}$ & $239.25 \mathrm{a}$ & $6.16 b$ & $24.00 \mathrm{~b}$ & $26.56 \mathrm{a}$ \\
\hline MAR20\#6 & $2,560.80 \mathrm{ab}$ & $12,154.06 \mathrm{ab}$ & $209.25 \mathrm{ab}$ & $158.20 \mathrm{ab}$ & $599.25 \mathrm{ab}$ & $255.00 \mathrm{a}$ & $0.00 \mathrm{~b}$ & $0.00 \mathrm{~b}$ & $0.00 \mathrm{a}$ \\
\hline UnB-P5 & $1,296.18 \mathrm{ab}$ & $5,661.56 \mathrm{ab}$ & $231.56 \mathrm{a}$ & $145.16 \mathrm{ab}$ & $599.25 \mathrm{ab}$ & $137.06 \mathrm{a}$ & $0.00 \mathrm{~b}$ & $0.00 \mathrm{~b}$ & $0.00 \mathrm{a}$ \\
\hline MAR20\#23 & $3,634.74 \mathrm{a}$ & $17,555.25 \mathrm{a}$ & $209.25 \mathrm{ab}$ & $161.40 \mathrm{ab}$ & $741.56 \mathrm{ab}$ & $202.06 \mathrm{a}$ & $0.00 \mathrm{~b}$ & $0.00 \mathrm{~b}$ & $0.00 \mathrm{a}$ \\
\hline UnB-P4 & $2,840.07 \mathrm{ab}$ & $15,128.00 \mathrm{ab}$ & $181.25 \mathrm{ab}$ & $506.59 \mathrm{ab}$ & $2,208.00 \mathrm{ab}$ & $224.00 \mathrm{a}$ & $0.00 \mathrm{~b}$ & $0.00 \mathrm{~b}$ & $0.00 \mathrm{a}$ \\
\hline UnB-P2 & $2,510.64 \mathrm{ab}$ & $12,768.00 \mathrm{ab}$ & $188.06 \mathrm{ab}$ & $390.62 \mathrm{ab}$ & $1,443.00 \mathrm{ab}$ & $255.00 \mathrm{a}$ & $10.40 \mathrm{~b}$ & $35.00 \mathrm{~b}$ & $29.25 \mathrm{a}$ \\
\hline UnB-P7 & $4,156.50 \mathrm{a}$ & $19,250.56 \mathrm{a}$ & $216.56 \mathrm{ab}$ & $510.15 \mathrm{ab}$ & $2,001.56 \mathrm{ab}$ & $149.06 \mathrm{a}$ & $0.00 \mathrm{~b}$ & $0.00 \mathrm{~b}$ & $0.00 \mathrm{a}$ \\
\hline MAR20\#03 & $2,899.36 \mathrm{ab}$ & $13,224.00 \mathrm{ab}$ & $224.00 \mathrm{ab}$ & $408.96 \mathrm{ab}$ & $1.599 .00 \mathrm{ab}$ & $255.00 \mathrm{a}$ & $16.64 \mathrm{ab}$ & $59.06 \mathrm{ab}$ & $89.25 \mathrm{a}$ \\
\hline EC-3-0 & $643.6 \mathrm{~b}$ & $3,874.06 \mathrm{~b}$ & $174.56 \mathrm{~b}$ & $24.88 \mathrm{ab}$ & $104.06 \mathrm{ab}$ & $67.06 \mathrm{a}$ & $0.00 \mathrm{~b}$ & $0.00 \mathrm{~b}$ & $0.00 \mathrm{a}$ \\
\hline MAR20\#10 & $1,781.56 \mathrm{ab}$ & $8,835.00 \mathrm{ab}$ & $195.00 \mathrm{ab}$ & $60.02 \mathrm{ab}$ & $296.57 \mathrm{ab}$ & $114.56 \mathrm{a}$ & $0.00 \mathrm{~b}$ & $0.00 \mathrm{~b}$ & $0.00 \mathrm{a}$ \\
\hline MAR20\#34 & $2,077.20 \mathrm{ab}$ & $10,049.06 \mathrm{ab}$ & $202.06 \mathrm{ab}$ & $142.51 \mathrm{ab}$ & $587.06 \mathrm{ab}$ & $137.06 \mathrm{a}$ & $0.00 \mathrm{~b}$ & $0.00 \mathrm{~b}$ & $0.00 \mathrm{a}$ \\
\hline MAR20\#21 & $1,459.26 \mathrm{ab}$ & 7,097.06 ab & $202.06 \mathrm{ab}$ & $54.17 \mathrm{ab}$ & $224.00 \mathrm{ab}$ & $143.00 \mathrm{a}$ & $0.00 \mathrm{~b}$ & $0.00 \mathrm{~b}$ & $0.00 \mathrm{a}$ \\
\hline FB200 & $1,462.28 \mathrm{ab}$ & $6,682.06 \mathrm{ab}$ & $216.56 \mathrm{ab}$ & $59.90 \mathrm{ab}$ & $296.56 \mathrm{ab}$ & $120.00 \mathrm{a}$ & $5.70 \mathrm{~b}$ & $24.00 \mathrm{~b}$ & $24.00 \mathrm{a}$ \\
\hline FP-01 & $1,737.78 \mathrm{ab}$ & $8,788.06 \mathrm{ab}$ & $195.00 \mathrm{ab}$ & $28.31 \mathrm{ab}$ & $109.25 \mathrm{ab}$ & $155.25 \mathrm{a}$ & $0.00 \mathrm{~b}$ & $0.00 \mathrm{~b}$ & $0.00 \mathrm{a}$ \\
\hline BRS GA1 & $1,639.04 \mathrm{ab}$ & 8,099.00 ab & $202.06 \mathrm{ab}$ & $67.08 \mathrm{ab}$ & $399.00 \mathrm{ab}$ & $120.00 \mathrm{a}$ & $0.00 \mathrm{~b}$ & $0.00 \mathrm{~b}$ & $0.00 \mathrm{a}$ \\
\hline EC-RAM & $1,698.46 \mathrm{ab}$ & $7,831.25 \mathrm{ab}$ & $216.56 \mathrm{ab}$ & $82.51 \mathrm{ab}$ & $350.56 \mathrm{ab}$ & $131.25 \mathrm{a}$ & $0.00 \mathrm{~b}$ & $0.00 \mathrm{~b}$ & $0.00 \mathrm{a}$ \\
\hline GA2 & $2,174.15 \mathrm{ab}$ & $10,815.00 \mathrm{ab}$ & $195.00 \mathrm{ab}$ & $121.63 \mathrm{ab}$ & $624.00 \mathrm{ab}$ & $195.00 \mathrm{a}$ & $0.00 \mathrm{~b}$ & $0.00 \mathrm{~b}$ & $0.00 \mathrm{a}$ \\
\hline Redondão & $1,598.33 \mathrm{ab}$ & $7,568.00 \mathrm{ab}$ & $202.06 \mathrm{ab}$ & $57.6 \mathrm{ab}$ & $224.00 \mathrm{ab}$ & $155.25 \mathrm{a}$ & $0.00 \mathrm{~b}$ & $0.00 \mathrm{~b}$ & $0.00 \mathrm{a}$ \\
\hline MAR20\#39 & $1,169.64 \mathrm{ab}$ & $6,083.00 \mathrm{ab}$ & $202.06 \mathrm{ab}$ & $81.22 \mathrm{ab}$ & $389.06 \mathrm{ab}$ & $120.00 \mathrm{a}$ & $0.00 \mathrm{~b}$ & $0.00 \mathrm{~b}$ & $0.00 \mathrm{a}$ \\
\hline
\end{tabular}


Table 3. Estimates of mean phenotypic $\left(V_{p}\right)$, genotypic $\left(V_{g}\right)$, and environmental variances $\left(V_{e}\right)$, mean broad sense heritability $\left(h^{2}\right)$, coefficient of genetic variation $\left(\mathrm{CV}_{\mathrm{g}}\right)$, and coefficient of relative variance $\left(\mathrm{CV}_{\mathrm{g}} / \mathrm{CV}_{\mathrm{e}}\right)$ for total yield (TY; $\mathrm{Kg}$ ha $\left.{ }^{-1}\right)$, total number of fruits per hectare (TNF), and total fruit weight (TFW; g) in 32 yellow passion fruit (Passiflora edulis Sims) genotypes cultivated in Brasilia, DF, Brazil.

\begin{tabular}{|c|c|c|c|}
\hline Genetic parameters & TY & TNF & TFW \\
\hline$\sigma_{p}^{2}$ & $305,608.45$ & $2,406.28$ & 0.39 \\
\hline$\sigma_{g}^{2}$ & $199,772.71$ & $1,716.97$ & 0.20 \\
\hline $\mathrm{CV}_{\mathrm{g}}$ & 14.70 & 15.06 & 4.09 \\
\hline $\mathrm{CV}_{\mathrm{g}} / \mathrm{CV}_{\mathrm{e}}$ & 0.69 & 0.79 & 0.52 \\
\hline
\end{tabular}

Table 4. Estimates of mean phenotypic $\left(\mathrm{V}_{\mathrm{p}}\right)$, genotypic $\left(\mathrm{V}_{\mathrm{g}}\right)$, and environmental variances $\left(\mathrm{V}_{\mathrm{e}}\right)$, mean broad sense heritability $\left(\mathrm{h}^{2}\right)$, coefficient of genetic variation $\left(\mathrm{CV}_{\mathrm{g}}\right)$, and coefficient of relative variance $\left(\mathrm{CV}_{\mathrm{g}} / \mathrm{CV}_{\mathrm{e}}\right)$ for yield $\left(\mathrm{Y} ; \mathrm{Kg} \mathrm{ha}^{-1}\right)$, number of fruits per hectare $(\mathrm{NF})$, and fruit weight $(\mathrm{FW} ; \mathrm{g})$ of diameter classes 1C, 1B, 1A, 2A, and 3A in 32 yellow passion fruit (Passiflora edulis Sims) genotypes cultivated in Brasilia, DF, Brazil.

\begin{tabular}{|c|c|c|c|c|c|c|c|c|c|c|c|c|c|c|c|}
\hline $\begin{array}{c}\text { Genetic } \\
\text { parameters }\end{array}$ & $\begin{array}{c}Y \\
1 C\end{array}$ & $\begin{array}{l}\text { NF } \\
1 \mathrm{C}\end{array}$ & $\begin{array}{r}\text { FW } \\
1 \mathrm{C} \\
\end{array}$ & $\begin{array}{c}Y \\
\mathbf{1 B} \\
\end{array}$ & $\begin{array}{l}\text { NF } \\
\text { 1B }\end{array}$ & $\begin{array}{c}\text { FW } \\
\mathbf{1 B}\end{array}$ & $\begin{array}{c}\mathbf{Y} \\
\mathbf{1 A} \\
\end{array}$ & $\begin{array}{l}\text { NF } \\
\mathbf{1 A}\end{array}$ & $\begin{array}{c}\text { FW } \\
\text { 1A }\end{array}$ & $\begin{array}{c}\mathbf{Y} \\
\mathbf{2 A}\end{array}$ & NF 2A & $\begin{array}{c}\text { FW } \\
2 A\end{array}$ & $\begin{array}{c}\mathbf{Y} \\
\mathbf{3 A} \\
\end{array}$ & $\begin{array}{l}\mathbf{N F} \\
\mathbf{3 A}\end{array}$ & $\begin{array}{l}\text { FW } \\
\text { 3A }\end{array}$ \\
\hline$\sigma_{p}^{2}$ & $115,268.71$ & $1,556.88$ & 0.25 & $188,934.94$ & $1,206.35$ & 0.26 & $83,431.72$ & 366.37 & 0.22 & $44,511.70$ & 161.92 & 8.19 & $4,811.06$ & 14.97 & 10.46 \\
\hline$\sigma_{\mathrm{e}}^{2}$ & $22,249.63$ & 285.44 & 0.14 & $64,613.05$ & 399.23 & 0.17 & $35,332.58$ & 150.42 & 0.11 & $17,727.21$ & 67.55 & 7.52 & $1,768.98$ & 5.41 & 4.77 \\
\hline$\sigma_{g}^{2}$ & $93,019.08$ & $1,271.44$ & 0.11 & $124,321.89$ & 807.11 & 0.09 & $48,099.14$ & 215.95 & 0.11 & $26,784.50$ & 94.37 & 0.67 & $3,042.08$ & 9.57 & 5.69 \\
\hline $\mathrm{h}^{2} \%$ & 80.7 & 81.7 & 43.86 & 65.8 & 66.91 & 35.1 & 57.65 & 58.94 & 50.85 & 60.17 & 58.28 & 8.17 & 63.23 & 63.9 & 54.41 \\
\hline $\mathrm{CV}_{\mathrm{g}}$ & 25.77 & 23.14 & 4.37 & 15.11 & 14.2 & 2.59 & 15.57 & 15 & 2.33 & 39.4 & 36.52 & 6.31 & 170.94 & 113.8 & 90.32 \\
\hline $\mathrm{CV}_{\mathrm{g}} / \mathrm{CV}_{\mathrm{e}}$ & 1.02 & 1.06 & 0.44 & 0.69 & 0.71 & 0.37 & 0.58 & 0.6 & 0.51 & 0.62 & 0.59 & 0.15 & 0.66 & 0.67 & 0.55 \\
\hline
\end{tabular}


Table 5. Estimates of phenotypic correlation $\left(r_{p}\right)$ among total number of fruits per hectare (TNF), total yield (TY; Kg ha $\left.{ }^{-1}\right)$, total fruit weight (TFW; $g$ ), and yield $\left(\mathrm{Y} ; \mathrm{Kg} \mathrm{ha}^{-1}\right)$, number of fruits per hectare $(\mathrm{NF})$, and fruit weight $(\mathrm{FW} ; \mathrm{g})$ of diameter classes $1 \mathrm{C}, 1 \mathrm{~B}, 1 \mathrm{~A}, 2 \mathrm{~A}$, and $3 \mathrm{~A}$, in 32 yellow passion fruit (Passiflora edulis Sims) genotypes cultivated in Brasilia, DF, Brazil.

\begin{tabular}{|c|c|c|c|c|c|c|c|c|c|c|c|c|c|c|c|c|c|c|}
\hline & TNF & TY & TFW & NF1C & Y1C & FW 1C & NF1B & Y1B & FW1B & NF1A & Y1A & FW1A & NF2A & Y2A & FW2A & NF3A & Y3A & FW3A \\
\hline TNF & 1 & $0.96^{*}$ & -0.13 & $0.90^{*}$ & $0.89 *$ & $0.57 *$ & $0.97 *$ & $0.95^{*}$ & 0.25 & $0.65^{*}$ & $0.65 *$ & 0.13 & 0.18 & 0.17 & 0.27 & -0.18 & -0.16 & -0.03 \\
\hline TY & - & 1 & 0.15 & $0.78^{*}$ & $0.81 *$ & $0.65 *$ & $0.94 *$ & $0.98 *$ & 0.43 & $0.78^{*}$ & $0.79 *$ & 0.3 & $0.35^{*}$ & 0.34 & 0.39 & -0.09 & -0.06 & 0.08 \\
\hline TFW & - & - & 1 & -0.34 & -0.24 & 0.25 & -0.10 & 0.08 & $0.64 *$ & $0.43 *$ & $0.48 *$ & $0.57 *$ & $0.60 *$ & $0.60 *$ & $0.39 *$ & $0.37 *$ & $0.39 *$ & 0.39 \\
\hline NF1C & - & - & - & 1 & $0.98 *$ & $0.54 *$ & $0.78 *$ & $0.79 *$ & 0.26 & 0.32 & 0.33 & 0.10 & -0.14 & -0.15 & -0.05 & -0.31 & -0.29 & -0.18 \\
\hline Y1C & - & - & - & - & 1 & $0.67 *$ & $0.79 *$ & $0.81 *$ & 0.34 & 0.34 & $0.36^{*}$ & 0.13 & -0.12 & -0.13 & -0.04 & -0.27 & -0.25 & -0.15 \\
\hline FW1C & - & - & - & - & - & 1 & $0.52 *$ & $0.63^{*}$ & $0.52 *$ & $0.40^{*}$ & $0.42 *$ & 0.22 & 0.11 & 0.11 & 0.09 & -0.04 & -0.01 & 0.07 \\
\hline NF1B & - & - & - & - & - & - & 1 & $0.97 *$ & 0.19 & $0.67 *$ & $0.67 *$ & 0.09 & 0.20 & 0.20 & $0.35^{*}$ & -0.18 & -0.16 & -0.01 \\
\hline Y1B & - & - & - & - & - & - & - & 1 & $0.41 *$ & $0.69 *$ & $0.70 *$ & 0.25 & 0.21 & 0.21 & 0.33 & -0.18 & -0.15 & 0.004 \\
\hline FW1B & - & - & - & - & - & - & - & - & 1 & 0.29 & $0.36^{*}$ & $0.70 *$ & 0.16 & 0.15 & 0.02 & 0.05 & 0.07 & 0.11 \\
\hline NF1A & - & - & - & - & - & - & - & - & - & 1 & $0.99 *$ & 0.30 & $0.74 *$ & $0.73 *$ & $0.65^{*}$ & 0.12 & 0.15 & 0.26 \\
\hline Y1A & - & - & - & - & - & - & - & - & - & - & 1 & $0.41 *$ & $0.73 *$ & $0.72 *$ & $0.64 *$ & 0.11 & 0.14 & 0.27 \\
\hline FW1A & - & - & - & - & - & - & - & - & - & - & - & 1 & 0.32 & 0.32 & 0.26 & 0.05 & 0.07 & 0.17 \\
\hline NF2A & - & - & - & - & - & - & - & - & - & - & - & - & 1 & $0.99 *$ & $0.75^{*}$ & $0.43^{*}$ & $0.45^{*}$ & $0.49 *$ \\
\hline Y2A & - & - & - & - & - & - & - & - & - & - & - & - & - & 1 & $0.76^{*}$ & $0.43 *$ & $0.45^{*}$ & $0.49 *$ \\
\hline FW2A & - & - & - & - & - & - & - & - & - & - & - & - & - & - & 1 & $0.34^{*}$ & $0.36^{*}$ & $0.41 *$ \\
\hline NF3A & - & - & - & - & - & - & - & - & - & - & - & - & - & - & - & 1 & $0.98^{*}$ & $0.92 *$ \\
\hline Y3A & - & - & - & - & - & - & - & - & - & - & - & - & - & - & - & - & 1 & $0.94 *$ \\
\hline FW3A & - & - & - & - & - & - & - & - & - & - & - & - & - & - & - & - & - & 1 \\
\hline
\end{tabular}


The total number of fruits was negatively correlated with the fruit weight $\left(r_{f}=-0.13\right)$, as also observed by Pimentel et al. (2008) and Neves et al. (2013) for genetic correlations in parents and hybrids of yellow passion fruit. Therefore, an increase in the number of fruits reduced fruits size, which is undesirable for the fresh fruit market. The total number of fruits negatively correlated with the number of fruits of $1 \mathrm{C}\left(\mathrm{r}_{\mathrm{f}}=-0.34\right)$ and $1 \mathrm{~B}\left(\mathrm{r}_{\mathrm{f}}=\right.$ $0.10)$ diameter classes, as well as with the yield of fruits of $1 \mathrm{C}$ diameter class $\left(r_{f}=-0.24\right)$. A negative correlation was also reported between the variables of fruits of smaller diameter class (1C and 1B) and the variables of fruits of greater diameter class $(2 \mathrm{~A}$ and 3A) (Table 5).

\section{CONCLUSIONS}

Genotypes MAR20\#23 and UnB-P7 presented the highest total yield, with values higher than the national mean. MAR20\#23 also showed the greatest total number of fruits per hectare, standing out from the other genotypes.

The highest yield and the greatest number of fruits suitable for industrial purposes (diameter classes 1C and 1B) were identified in genotypes BRS GA1 and MAR20\#23.

For the in natura consumption, the best performance was verified in UnB-P7, AR-01, and MSC (diameter classes 1A, 2A, and 3A, respectively).

High heritability values and $\mathrm{CV}_{\mathrm{g}} / \mathrm{CV}_{\mathrm{e}}$ ratio greater than 1 for yield and number of fruits of $1 \mathrm{C}$ diameter class indicate a favorable selection condition.

The differences in yield and fruit quality recorded for the genotypes of this study confirm the potential for selection and future crosses that aim at increasing these traits. 
RESUMO: A seleção de genótipos de maracujazeiro azedo (Passiflora edulis Sims) que apresentem alta produtividade e qualidade de frutos é essencial para o desenvolvimento da cultura do maracujá no país. Portanto, este trabalho teve como objetivo avaliar o desempenho agronômico e de estimar parâmetros genéticos de 32 genótipos de maracujazeiro azedo cultivados no Distrito Federal, Brasil. O experimento consistiu de um delineamento em blocos casualizados com 32 tratamentos, oito plantas por parcela, e quatro repetições. Os frutos foram classificados de acordo com o seu diâmetro equatorial. Produtividade, número de frutos por hectare e peso de frutos foram avaliados. Os genótipos MAR20\#23 e UNB-P7 apresentaram as maiores produtividades totais, com valores superiores à média nacional. MAR20\#23 também mostrou o maior número total de frutos por hectare. BRA GA1 e MAR20\#23 exibiram a melhor performance para frutos de menores classes de diâmetro, que são destinados a fins industriais. Para o consumo in natura (frutos de maiores classes de diâmetro), UnB-P7, AR-01 e MSC apresentaram o melhor desempenho. As altas magnitudes das estimativas de herdabilidade e dos coeficientes de variação genéticos indicam a possibilidade de maiores ganhos por seleção direta para produtividade e número de frutos classe 1C. Correlações fenotípicas significativas foram observadas, indicando a possibilidade de seleção indireta para número de frutos, peso de frutos e produtividade.

PALAVRAS-CHAVE: Desempenho agronômico; Melhoramento vegetal; Passicultura.

\section{REFERENCES}

ABREU, S. P. M.; PEIXOTO, J. R.; JUNQUEIRA, N. T. V.; SOUSA, M. A. F. Características agronômicas de seis genótipos de maracujazeiro-azedo cultivados no Distrito Federal. Revista Brasileira de Fruticultura, v. 31, n. 3, p. 920-924, 2009. https://doi.org/10.1590/S0100-29452009000300042

BALBINO, J. M. S. Manejo na colheita e pós-colheita do maracujá. In: COSTA, A. F. S.; COSTA, A. N. (Ed.). Tecnologias para a produção de maracujá. Vitória: Incaper, 2005. p. 153-179.

CAMPOS, V. B.; CAVALCANTE, L. F.; DANTAS, T. A. G.; MOTA, J. K. M.; RODRIGUES, A. C.; DINIZ, A. A. Caracterização física e química de frutos de maracujazeiro-amarelo sob adubação potássica, biofertilizante e cobertura morta. Revista Brasileira de Produtos Agroindustriais, v. 9, n. 1, p. 59-71, 2007. https://doi.org/10.15871/1517-8595/rbpa.v9n1p59-71

CARVALHO, F. I. F.; LORENCETTI, C.; BENIN, G. Estimativas e implicações da correlação no melhoramento vegetal. Pelotas: Editora e Gráfica Universitária - UFPel, 2004. 141p.

COIMBRA, K. G.; PEIXOTO, J. R.; SOUSA, M. A. F.; JUNQUEIRA, N. T. V. Produtividade e qualidade de frutos de progênies de maracujazeiro-azedo cultivados no Distrito Federal. Revista Brasileira de Fruticultura, v. 34, n. 4, p. 1121-1128, 2012. https://doi.org/10.1590/S0100-29452012000400020

COSTA, A. F. S.; COSTA, A. N.; VENTURA, J. A.; FANTON, C. J.; LIMA, I. M.; CAETANO, L. C. S.; SANTANA, E. N. Recomendações técnicas para o cultivo do maracujazeiro. Vitória: Incaper, 2008. 56p. (Documentos, 162).

CRUZ, C. D. GENES: a software package for analysis in experimental statistics and quantitative genetics. Acta Scientiarum. Agronomy, v. 35, n. 3, p. 271-276, 2013. https://doi.org/10.4025/actasciagron.v35i3.21251

FALEIRO, F. G.; PEIXOTO, J. R.; VIANA, A. P.; BRUCKNER, C. H.; LARANJEIRA, F. F.; DAMASCENO, F.; MELETTI, L. M. M.; CONSOLI, L.; SOUSA, M. A. F.; SILVA, M. S.; PEREIRA, M. G.; STENZEL, N.; SHARMA, R. D. Demandas para pesquisas relacionadas ao melhoramento genético. In: FALEIRO, F. G.; JUNQUEIRA, N. T.; BRAGA, M. F. (Ed). Maracujá: Demandas para a pesquisa. Brasília: Embrapa, 2006. p. 25-29.

FERREIRA, F. M.; NEVES, L. G.; BRUCKNER, C. H.; VIANA, A. P.; CRUZ, C. D.; BARELLI, M. A. A. Formação de super-caracteres para seleção de famílias de maracujazeiro amarelo. Acta Scientiarum.

Agronomy, v. 32, n. 2, p. 247-254, 2010. https://doi.org/10.4025/actasciagron.v32i2.3328 
FREITAS, J. C. O.; PIO VIANA, A.; SANTOS, E. A.; SILVA, F. H. L.; PAIVA, C. L.; RODRIGUES, R.; SOUZA, M. M.; EIRAS, M. Genetic basis of the resistance of a passion fruit segregant population to Cowpea aphid-borne mosaic virus (CABMV). Tropical Plant Pathology, v. 40, p. 291-297, 2015. https://doi.org/10.1007/s40858-015-0048-2

FREITAS, J. P. X.; OLIVEIRA, E. J.; CRUZ NETO, A. J.; SANTOS, L. R. Avaliação de recursos genéticos do maracujazeiro-amarelo. Pesquisa Agropecuária Brasileira, v. 46, n. 9, p. 1013-1020, 2011. https://doi.org/10.1590/S0100-204X2011000900007

FREITAS, J. P. X.; OLIVEIRA, E. J.; JESUS, O. N.; CRUZ NETO, A. J.; SANTOS, L. R. Formação de população base para seleção recorrente em maracujazeiro-amarelo com uso de índices de seleção. Pesquisa Agropecuária Brasileira, v. 47, n. 3, p. 393-401, 2012. https://doi.org/10.1590/S0100-204X2012000300011

IBGE - Instituto Brasileiro de Geografia e Estatística. Produção Agrícola Municipal - Culturas temporárias e permanentes. Rio de Janeiro: IBGE, 2016. 62 p.

JUNQUEIRA, N. T. V.; ANJOS, J. R. N.; SILVA, A. P. O.; CHAVES, R. C.; GOMES, A. C. Reação às doenças e produtividade de onze cultivares de maracujá-azedo cultivadas sem agrotóxicos. Pesquisa Agropecuária Brasileira, v. 38, n. 8, p. 1005-1010, 2003. https://doi.org/10.1590/S0100-204X2003000800014

JUNQUEIRA, N. T. V.; ICUMA, I. M.; VERAS, M. C. M.; OLIVEIRA, M. A. S.; DOS ANJOS, J. R. N. Cultura do maracujazeiro. In: SILVA, J. M. M. (Ed.). Incentivo a fruticultura no Distrito Federal: manual de fruticultura. Brasília: COOLABORA, 1999. p. 42-52.

KRAUSE, W.; NEVES, L. G.; VIANA, A. P.; ARAÚJO, C. A. T.; FALEIRO, F. G. Produtividade e qualidade de frutos de cultivares de maracujazeiro-amarelo com ou sem polinização artificial. Pesquisa Agropecuária Brasileira, v. 47, n. 12, p. 1737-1742, 2012. https://doi.org/10.1590/S0100-204X2012001200009

KUREK, A. J.; CARVALHO, F. I. F.; OLIVEIRA, A. C.; CARGNIN, A.; MARCHIORO, V. S.; LORENCETTI, C. Coeficiente de correlação entre caracteres agronômicos e de qualidade de grãos e sua utilidade na seleção de plantas de aveia. Ciência Rural, v. 32, n. 3, p. 371-376, 2002. https://doi.org/ $10.1590 / \mathrm{S} 0103-84782002000300002$

MAIA, T. E. G.; PEIXOTO, J. R.; JUNQUEIRA, N. T. V.; SOUSA, M. A. F. Desempenho agronômico de genótipos de maracujazeiro cultivados no Distrito Federal. Revista Brasileira de Fruticultura, v. 31, n. 2, p. 500-506, 2009. https://doi.org/10.1590/S0100-29452009000200026

MELO, K. T.; MANICA, I.; JUNQUEIRA, N. T. V. Produtividade de seis cultivares de maracujazeiro-azedo durante três anos em Vargem Bonita, DF. Pesquisa Agropecuária Brasileira, v. 36, n. 9, p. 1117-1125, 2001. https://doi.org/10.1590/S0100-204X2001000900005

MELETTI; L. M. M.; SANTOS, R. R.; MINAMI, K. Melhoramento do maracujazeiro-amarelo: obtenção do cultivar 'Composto IAC-27'. Scientia Agricola, v. 57, n. 3, p. 491-498, 2000. https://doi.org/10.1590/S010390162000000300019

NEVES, C. G.; JESUS, O. N.; LEDO, C. A. S.; OLIVEIRA, E. J. Avaliação agronômica de parentais e híbridos de maracujazeiro-amarelo. Revista Brasileira de Fruticultura, v. 35, n. 1, p. 191-198, 2013. https://doi.org/10.1590/S0100-29452013000100022

OLIVEIRA, E. J.; SANTOS, V. S.; LIMA, D. S.; MACHADO, M. D.; LUCENA, R. S; MOTTA, T. B. N. Estimativas de correlações genotípicas e fenotípicas em germoplasma de maracujazeiro. Bragantia, v. 70, n. 2, p. 255-261, 2011. https://doi.org/10.1590/S0006-8705201100020000

OLIVEIRA, E. J.; SANTOS, V. S.; LIMA, D. S.; MACHADO, M. D.; LUCENA, R. S.; MOTTA, T. B. N.; CASTELLEN, M. S. Seleção em progênies de maracujazeiro amarelo com base em índices multivariados. 
Pesquisa Agropecuária Brasileira, v. 43, n. 11, p. 1543-1549, 2008. https://doi.org/10.1590/S0100204X2008001100013

PIMENTEL, L. D.; STENZEL, N. M. C.; CRUZ, C. D.; BRUCKNER, C. H. Seleção precoce de maracujazeiro pelo uso da correlação entre dados de produção mensal e anual. Pesquisa Agropecuária Brasileira, v. 43, n. 10, p. 1303-1309, 2008. https://doi.org/10.1590/S0100-204X2008001000007

VALE, L. S. R.; MATOS, G. R.; SOARES, R. S.; SILVA, J. K. R. M. Desempenho agronômico de cultivares de maracujazeiro híbrido. Global Science and Technology, v. 6, n. 3, p. 178-183, 2013.

https://doi.org/10.14688/1984-3801.v06n03a18

VASCONCELLOS, N. J. S.; CARVALHO, F. I. F.; COIMBRA, J.; SILVA, S. A.; MARCHIORO, V. S.; AZEVEDO, R.; LORECETTI, C. Efeito do ambiente e correlação entre componentes do grão em genótipos de aveia cultivados no Sul do Brasil. Revista Brasileira de Agrociência, v. 2, p. 85-88, 1998. 